\title{
Copper-Mediated N-Alkynylation of Carbamates, Ureas, and Sulfonamides. A General Method for the Synthesis of Ynamides
}

\author{
Joshua R. Dunetz and Rick L. Danheiser* \\ Department of Chemistry \\ Massachusetts Institute of Technology \\ Cambridge, Massachusetts 02139
}

\section{Supporting Information}

General Procedures. All reactions were performed in flame-dried or oven-dried glassware under

a positive pressure of argon. Reaction mixtures were stirred magnetically unless otherwise indicated. Air- and moisture-sensitive liquids and solutions were transferred by syringe or cannula and were introduced into reaction vessels through rubber septa. Reaction product solutions and chromatography fractions were concentrated by rotary evaporation at ca. $20 \mathrm{mmHg}$ and then at ca. $0.1 \mathrm{mmHg}$ (vacuum pump) unless otherwise indicated. Thin layer chromatography was performed on Merck precoated glassbacked silica gel 60 F-254 0.25 mm plates. Column chromatography was performed on EM Science silica gel 60 or Silicycle silica gel 60 (230-400 mesh).

Materials. Commercial grade reagents and solvents were used without further purification except as indicated below. Pyridine was distilled under argon from potassium hydroxide and degassed with argon bubbling prior to use. Copper(I) iodide was extracted with THF for $24 \mathrm{~h}$ in a Soxhlet extractor and then dried under vacuum $(0.1 \mathrm{mmHg})$. Carbamates $8 \mathbf{a}, \mathbf{8 b}$, and $\mathbf{8 c}$ were prepared by reaction of the corresponding amines with 1.1 equiv of pyridine and 1.1 equiv of methyl chloroformate in $\mathrm{CH}_{2} \mathrm{Cl}_{2}(\mathrm{rt}, 1$ h). Carbamate $\mathbf{8 d}$ was prepared by reaction of benzylamine with 1.1 equiv of triethylamine and 1.1 equiv of di-tert-butyl dicarbonate in $\mathrm{CH}_{2} \mathrm{Cl}_{2}(\mathrm{rt}, 14 \mathrm{~h})$. Sulfonamide 13 was prepared by treatment of benzylamine with 1.1 equiv of triethylamine and 1.1 equiv of $p$-toluenesulfonyl chloride in $\mathrm{CH}_{2} \mathrm{Cl}_{2}(\mathrm{rt}, 8$ 
h). Alkynyl bromides $\mathbf{1 0 a ^ { 1 }}$ and $\mathbf{1 0 f ^ { 2 }}$ and were prepared as previously reported by reaction with $\mathrm{AgNO}_{3}$ and NBS using the general method of Hofmeister and co-workers. ${ }^{3}$ Alkynyl bromides 10c, ${ }^{4} \mathbf{1 0 e},{ }^{5}$ and $\mathbf{1 0 g}^{6}$ were prepared from the corresponding terminal alkynes using the method of Hofmeister and coworkers $\left(\mathrm{AgNO}_{3}, \mathrm{NBS}\right) .^{3}$ Alkynyl bromides $\mathbf{1 0 b}^{7}$ and $\mathbf{1 0 d ^ { 8 }}$ were prepared by bromination of the corresponding alkynylsilanes as previously reported using the general method of Miller and Zweifel $\left(\mathrm{MeLi}-\mathrm{LiBr}, \mathrm{Br}_{2}\right){ }^{7}$ Halo alkynes were stored at $-20{ }^{\circ} \mathrm{C}$ as $0.6 \mathrm{M}$ stock solutions in benzene. ${ }^{9}$ Caution: Alkynyl bromides are strong lachrymators!

Instrumentation. Melting points were determined with a Fisher-Johns melting point apparatus and are uncorrected. Infrared spectra were obtained using a Perkin Elmer 2000 FT-IR spectrophotometer. ${ }^{1} \mathrm{H}$ NMR and ${ }^{13} \mathrm{C}$ NMR spectra were measured with an Inova 500 spectrometer. ${ }^{1} \mathrm{H}$ NMR chemical shifts are expressed in parts per million ( $\square$ ) downfield from tetramethylsilane (with the $\mathrm{CHCl}_{3}$ peak at $7.27 \mathrm{ppm}$

used as a standard. ${ }^{13} \mathrm{C}$ NMR chemical shifts are expressed in parts per million $(\square)$ downfield from tetramethylsilane (with the central peak of $\mathrm{CHCl}_{3}$ at $77.23 \mathrm{ppm}$ used as a standard). High resolution mass spectra (HRMS) were measured on a Bruker Daltonics APEXII 3 telsa fourier transform mass spectrometer. Elemental analyses were performed by E\&R Microanalytical Laboratory, Inc. of Parsippany, NJ.

\section{General Procedure for the Coupling of Amides with Bromo Alkynes. $N$-Methoxycarbonyl-} $N$-(2-phenylethyl)-2-phenylethynylamine (9a). A 250-mL, two-necked, round-bottomed flask equipped with a rubber septum and addition funnel fitted with a rubber septum and argon inlet needle was charged with carbamate $8 \mathbf{a}(1.951 \mathrm{~g}, 10.89 \mathrm{mmol})$ and $44 \mathrm{~mL}$ of pyridine. The solution was cooled at $0{ }^{\circ} \mathrm{C}$ while

${ }^{1}$ Li, L.-S.; Wu, Y.-L. Tetrahedron Lett. 2002, 43, 2427.

2 Rubin, Y.; Lin, S. S.; Knobler, C. B.; Anthony, J.; Boldi, A. M.; Diederich, F. J. Am. Chem. Soc. 1991, 113, 6943.

3 Hofmeister, H.; Annen, K.; Laurent, H.; Wiechert, R. Angew. Chem., Int. Ed. Engl. 1984, 23, 727.

${ }^{4}$ Early preparation of this compound involved the elimination of 3,4-dibromostyrene as reported by A. A. Petrov in Chem. Abstr. 1944, 1466.

${ }^{5}$ For a previous synthesis of this compound from 1-octyne with AgOAc and NBS, see Chen, C.; Crich, D. J. Chem. Soc., Chem. Commun. 1991, 18, 1289.

6 For a previous synthesis of this compound, see Stefani, H. A.; Menezes, P. H.; Costa, I. M.; Silva, D. O.; Petragnani, N. Synlett 2002, 8, 1335.

${ }^{7}$ Miller, J. A.; Zweifel, G. Synthesis 1983, 128.

8 Basak, S.; Srivastava, S.; le Noble, W. J. J. Org. Chem. 1987, 52, 5095.

${ }^{9}$ Alkynyl bromide 10d stored as $0.4 \mathrm{M}$ stock solution in benzene. 
$12.0 \mathrm{~mL}$ of KHMDS solution $(0.91 \mathrm{M}$ in THF, $11 \mathrm{mmol})$ was added via syringe over $4 \mathrm{~min}$. The reaction mixture was stirred at $0{ }^{\circ} \mathrm{C}$ for $10 \mathrm{~min}$ and then a solution of $\mathrm{CuI}(2.073 \mathrm{~g}, 10.89 \mathrm{mmol})$ in $22 \mathrm{~mL}$ of pyridine was added via cannula in one portion (10-mL pyridine rinse). The ice bath was removed, and the resulting solution was stirred at room temperature for $2 \mathrm{~h}$. A solution of bromo alkyne $\mathbf{1 0 a}(36 \mathrm{~mL}, 0.60$ $\mathrm{M}$ in benzene, $22 \mathrm{mmol}$ ) was then added via the addition funnel over $1 \mathrm{~h}$, and the resulting mixture was stirred at room temperature for $20 \mathrm{~h}$. The reaction mixture was diluted with $300 \mathrm{~mL}$ of $\mathrm{Et}_{2} \mathrm{O}$ and washed with three $100-\mathrm{mL}$ portions of a 2:1 mixture of saturated $\mathrm{NaCl}$ and concentrated $\mathrm{NH}_{4} \mathrm{OH}$. The combined aqueous layers were extracted with three $75-\mathrm{mL}$ portions of $\mathrm{Et}_{2} \mathrm{O}$, and the combined organic layers were washed with $300 \mathrm{~mL}$ of saturated $\mathrm{NaCl}$, dried over $\mathrm{MgSO}_{4}$, filtered, and concentrated to provide $4.397 \mathrm{~g}$ of a dark red oil. Column chromatography on $120 \mathrm{~g}$ of silica gel (gradient elution with 0-3\% EtOAchexanes) provided $2.309 \mathrm{~g}$ (76\%) of ynamide 9a as a yellow oil: IR (neat): 3028, 2953, 2245, 1729, 1600, 1496, 1442, 1395, 1363, 1307, 1245, and $1147 \mathrm{~cm}^{-1} ;{ }^{1} \mathrm{H}$ NMR $\left(500 \mathrm{MHz}, \mathrm{CDCl}_{3}\right) \square 7.48(\mathrm{~d}, J=6.7 \mathrm{~Hz}$, 2H), 7.28-7.39 (m, 8H), $3.88(\mathrm{t}, J=7.5 \mathrm{~Hz}, 2 \mathrm{H}), 3.84(\mathrm{~s}, 3 \mathrm{H})$, and $3.11(\mathrm{t}, J=7.5 \mathrm{~Hz}, 2 \mathrm{H}) ;{ }^{13} \mathrm{C}$ NMR $(125$ $\left.\mathrm{MHz}, \mathrm{CDCl}_{3}\right) \square 155.6,138.0,131.4,129.0,128.6,128.3,127.7,126.7,123.2,82.7,71.0,54.1,51.4$, and 34.2; HRMS-ESI $m / z$ : $[\mathrm{M}+\mathrm{Na}]^{+}$calcd for $\mathrm{C}_{18} \mathrm{H}_{17} \mathrm{NO}_{2}, 302.1151$; found, 302.1141. Anal. Calcd for $\mathrm{C}_{18} \mathrm{H}_{17} \mathrm{NO}_{2}$ : C, 77.40; H, 6.13; N, 5.01. Found: C, 77.26; H, 6.23; N, 5.32.

$\mathrm{N}$-Methoxycarbonyl- $\mathrm{N}$-(2-phenylethyl)-2-(trimethylsilyl)ethynylamine (9b). Reaction of a solution of carbamate $\mathbf{8 a}(0.157 \mathrm{~g}, 0.876 \mathrm{mmol})$ in $3.5 \mathrm{~mL}$ of pyridine with KHMDS $(0.97 \mathrm{~mL}, 0.91 \mathrm{M}$ in THF, $0.88 \mathrm{mmol})$, CuI $(0.167 \mathrm{~g}, 0.877 \mathrm{mmol})$ in $2.3 \mathrm{~mL}$ of pyridine, and bromo alkyne $\mathbf{1 0 b}(2.9 \mathrm{~mL}, 0.60$ $\mathrm{M}$ in benzene, $1.7 \mathrm{mmol}$ ) according to the general procedure gave $0.282 \mathrm{~g}$ of a dark red oil. Column chromatography on $25 \mathrm{~g}$ of silica gel (gradient elution with 0-5\% EtOAc-hexanes) provided $0.135 \mathrm{~g}$ (56\%) of ynamide 9b as a pale yellow oil: IR (neat): 3029, 2956, 2898, 2176, 1736, 1604, 1498, 1443, 1375, 1282, 1249, 1202, and $1124 \mathrm{~cm}^{-1} ;{ }^{1} \mathrm{H}$ NMR (500 MHz, $\left.\mathrm{CDCl}_{3}\right) \square 7.32$ (m, 2H), 7.25 (m, 3H), 3.78 $(\mathrm{s}, 3 \mathrm{H}), 3.72(\mathrm{t}, J=7.6 \mathrm{~Hz}, 2 \mathrm{H}), 2.99(\mathrm{t}, J=7.6 \mathrm{~Hz}, 2 \mathrm{H})$, and $0.22(\mathrm{~s}, 9 \mathrm{H}) ;{ }^{13} \mathrm{C} \mathrm{NMR}\left(125 \mathrm{MHz}, \mathrm{CDCl}_{3}\right) \square$ $155.5,138.0,128.9,128.6,126.6,95.4,72.9,54.0,51.2,33.9$, and 0.3; HRMS-EI $m / z:[\mathrm{M}]^{+}$calcd for $\mathrm{C}_{15} \mathrm{H}_{21} \mathrm{NO}_{2} \mathrm{Si}$, 275.1337; found, 275.1341.

$N$-Methoxycarbonyl- $N$-(2-phenylethyl)-3-methyl-3-buten-1-ynylamine (9c). Reaction of a solution of carbamate 8a $(0.244 \mathrm{~g}, 1.36 \mathrm{mmol})$ in $5.4 \mathrm{~mL}$ of pyridine with KHMDS $(1.5 \mathrm{~mL}, 0.91 \mathrm{M}$ in THF, $1.4 \mathrm{mmol}), \mathrm{CuI}(0.260 \mathrm{~g}, 1.37 \mathrm{mmol})$ in $3.7 \mathrm{~mL}$ of pyridine, and bromo alkyne $10 \mathrm{c}(4.7 \mathrm{~mL}, 0.58 \mathrm{M}$ 
in benzene, $2.7 \mathrm{mmol}$ ) according to the general procedure gave $0.486 \mathrm{~g}$ of a dark red oil. Column chromatography on $35 \mathrm{~g}$ of silica gel (gradient elution with 0-3\% EtOAc-hexanes) afforded $0.216 \mathrm{~g}$ (65\%) of ynamide 9c as a pale yellow oil: IR (neat): 3028, 2954, 2234, 1730, 1614, 1497, 1444, 1402 , 1367, 1309, 1280, 1251, and $1177 \mathrm{~cm}^{-1}$; ${ }^{1} \mathrm{H}$ NMR (500 MHz, $\left.\mathrm{CDCl}_{3}\right) \square 7.32(\mathrm{~m}, 2 \mathrm{H}), 7.25$ (m, 3H), 5.23 $(\mathrm{s}, 1 \mathrm{H}), 5.17(\mathrm{~s}, 1 \mathrm{H}), 3.77(\mathrm{~s}, 3 \mathrm{H}), 3.76(\mathrm{t}, J=7.5 \mathrm{~Hz}, 2 \mathrm{H}), 3.00(\mathrm{t}, J=7.5 \mathrm{~Hz}, 2 \mathrm{H})$, and $1.94(\mathrm{~s}, 3 \mathrm{H}) ;{ }^{13} \mathrm{C}$ NMR $\left(125 \mathrm{MHz}, \mathrm{CDCl}_{3}\right) \square 155.4,137.9,128.9,128.5,126.6,126.3,119.5,82.0,72.3,53.9,51.2,34.1$, and 23.7; HRMS-ESI $m / z$ : $[\mathrm{M}+\mathrm{Na}]^{+}$calcd for $\mathrm{C}_{15} \mathrm{H}_{17} \mathrm{NO}_{2}, 266.1151$; found, 266.1155.

$N$-Methoxycarbonyl- $N$-(2-phenylethyl)-4-(trimethylsilyl)-1,3-butadiynylamine (9d). Reaction of a solution of carbamate $\mathbf{8 a}(0.195 \mathrm{~g}, 1.08 \mathrm{mmol})$ in $4.3 \mathrm{~mL}$ of pyridine with KHMDS $(1.2 \mathrm{~mL}, 0.91 \mathrm{M}$ in THF, $1.1 \mathrm{mmol}), \mathrm{CuI}(0.209 \mathrm{~g}, 1.10 \mathrm{mmol})$ in $3.2 \mathrm{~mL}$ of pyridine, and bromo alkyne $\mathbf{1 0 d}(5.4 \mathrm{~mL}, 0.40$ $\mathrm{M}$ in benzene, $2.2 \mathrm{mmol}$ ) according to the general procedure gave $0.451 \mathrm{~g}$ of a dark red oil. Column chromatography on $40 \mathrm{~g}$ of silica gel (gradient elution with 0-2\% EtOAc-hexanes) provided $0.128 \mathrm{~g}$ (40\%) of ynamide 9d as a yellow oil: IR (neat): 3029, 2957, 2232, 2113, 1741, 1604, 1497, 1440, 1396, 1359, 1293, 1250, 1205, and $1131 \mathrm{~cm}^{-1}$; ${ }^{1} \mathrm{H} \mathrm{NMR}$ (500 MHz, $\mathrm{CDCl}_{3}$ ) $\square 7.31$ (m, 2H), 7.23 (m, 3H), 3.77 $(\mathrm{s}, 3 \mathrm{H}), 3.71(\mathrm{t}, J=7.8 \mathrm{~Hz}, 2 \mathrm{H}), 2.97(\mathrm{t}, J=7.8 \mathrm{~Hz}, 2 \mathrm{H})$, and $0.23(\mathrm{~s}, 9 \mathrm{H}) ;{ }^{13} \mathrm{C} \mathrm{NMR}\left(125 \mathrm{MHz}, \mathrm{CDCl}_{3}\right) \square$ $155.6,137.5,129.0,128.7,126.9,90.0,87.6,69.5,58.7,54.5,51.2,34.2$, and -0.2 ; HRMS-ESI $m / z$ : $[\mathrm{M}+\mathrm{H}]^{+}$calcd for $\mathrm{C}_{17} \mathrm{H}_{21} \mathrm{NO}_{2} \mathrm{Si}, 300.1414$; found, 300.1424 .

$N$-Benzyl- $N$-methoxycarbonyl-1-octynylamine (9e). Reaction of a solution of carbamate $8 \mathrm{~b}$ $(0.150 \mathrm{~g}, 0.908 \mathrm{mmol})$ in $3.6 \mathrm{~mL}$ of pyridine with KHMDS (1.0 mL, 0.91 M in THF, $0.91 \mathrm{mmol}), \mathrm{CuI}$ $(0.174 \mathrm{~g}, 0.914 \mathrm{mmol})$ in $2.8 \mathrm{~mL}$ of pyridine, and bromo alkyne $10 \mathrm{e}(3.0 \mathrm{~mL}, 0.60 \mathrm{M}$ in benzene, 1.8 mmol) according to the general procedure gave $0.402 \mathrm{~g}$ of a dark brown oil. Column chromatography on $25 \mathrm{~g}$ of silica gel (gradient elution with 0-5\% EtOAc-hexanes) provided $0.123 \mathrm{~g}(50 \%)$ of ynamide $9 \mathrm{e}$ as a red oil: IR (neat): 3033, 2931, 2858, 2263, 1728, 1606, 1497, 1444, 1389, 1360, 1286, 1219, and 1128 $\mathrm{cm}^{-1} ;{ }^{1} \mathrm{H}$ NMR $\left(500 \mathrm{MHz}, \mathrm{CDCl}_{3}\right) \square 7.30-7.37(\mathrm{~m}, 5 \mathrm{H}), 4.60(\mathrm{~s}, 2 \mathrm{H}), 3.80(\mathrm{~s}, 3 \mathrm{H}), 2.25(\mathrm{t}, J=7.0 \mathrm{~Hz}$, 2H), $1.45(\operatorname{app} q u i n t e t, J=7.0 \mathrm{~Hz}, 2 \mathrm{H}), 1.22-1.35(\mathrm{~m}, 6 \mathrm{H})$, and $0.89(\mathrm{t}, J=7.0 \mathrm{~Hz}, 3 \mathrm{H}) ;{ }^{13} \mathrm{C}$ NMR $(125$ $\left.\mathrm{MHz}, \mathrm{CDCl}_{3}\right) \square 156.3,136.4,128.5,128.5,128.0,73.9,70.7,54.0,54.0,31.5,29.0,28.5,22.7,18.5$, and 14.2; HRMS-ESI $m / z$ : $[\mathrm{M}+\mathrm{Na}]^{+}$calcd for $\mathrm{C}_{17} \mathrm{H}_{23} \mathrm{NO}_{2}, 296.1621$; found, 296.1608.

$N$-Benzyl- $N$-methoxycarbonyl-(2-triisopropylsilyl)ethynylamine (9f). Reaction of a solution of carbamate $8 \mathbf{b}(0.205 \mathrm{~g}, 1.24 \mathrm{mmol})$ in $5.0 \mathrm{~mL}$ of pyridine with KHMDS (1.4 mL, $0.91 \mathrm{M}$ in THF, 1.3 
$\mathrm{mmol})$, $\mathrm{CuI}(0.244 \mathrm{~g}, 1.28 \mathrm{mmol})$ in $3.5 \mathrm{~mL}$ of pyridine, and bromo alkyne $\mathbf{1 0 f}(4.1 \mathrm{~mL}, 0.60 \mathrm{M}$ in benzene, $2.5 \mathrm{mmol}$ ) according to the general procedure gave $0.909 \mathrm{~g}$ of a dark red oil. Column chromatography on $35 \mathrm{~g}$ of silica gel (gradient elution with 0-5\% EtOAc-hexanes) provided $0.317 \mathrm{~g}$ (74\%) of ynamide 9f as a yellow oil: IR (neat): 3033, 2943, 2865, 2176, 1733, 1606, 1497, 1442, 1370, 1271, 1225, and $1123 \mathrm{~cm}^{-1} ;{ }^{1} \mathrm{H}$ NMR (500 MHz, $\left.\mathrm{CDCl}_{3}\right) \square 7.41$ (m, 2H), 7.30-7.36 (m, 3H), 4.64 (s, 2H), $3.80(\mathrm{~s}, 3 \mathrm{H})$, and 1.06-1.08 (app s, 21H); $\left.{ }^{13} \mathrm{C} \mathrm{NMR} \mathrm{(125} \mathrm{MHz,} \mathrm{CDCl}_{3}\right) \square 155.8,135.9,128.6,128.5$, 128.0, 97.0, 69.2, 53.9, 53.7, 18.6, and 11.4; HRMS-EI m/z: $[\mathrm{M}]^{+}$calcd for $\mathrm{C}_{20} \mathrm{H}_{31} \mathrm{NO}_{2} \mathrm{Si}, 345.2119$; found, 345.2107.

$\mathrm{N}$-Cyclohexyl- $\mathrm{N}$-methoxycarbonyl-2-phenylethynylamine (9g). Reaction of a solution of carbamate 8c $(0.170 \mathrm{~g}, 1.08 \mathrm{mmol})$ in $4.4 \mathrm{~mL}$ of pyridine with KHMDS $(1.2 \mathrm{~mL}, 0.91 \mathrm{M}$ in THF, 1.1 $\mathrm{mmol}), \mathrm{CuI}(0.209 \mathrm{~g}, 1.10 \mathrm{mmol})$ in $3.2 \mathrm{~mL}$ of pyridine, and bromo alkyne $10 \mathrm{a}(3.6 \mathrm{~mL}, 0.60 \mathrm{M}$ in benzene, $2.2 \mathrm{mmol}$ ) according to the general procedure gave $0.501 \mathrm{~g}$ of a dark red oil. Column chromatography on $35 \mathrm{~g}$ of silica gel (gradient elution with 0-3\% EtOAc-hexanes) provided $0.118 \mathrm{~g}$ (42\%) of ynamide 9g as a yellow oil: IR (neat): 2933, 2857, 2247, 1728, 1599, 1440, 1402, 1357, 1295, and $1245 \mathrm{~cm}^{-1}$; ${ }^{1} \mathrm{H}$ NMR $\left(500 \mathrm{MHz}, \mathrm{CDCl}_{3}\right) \square 7.43(\mathrm{~m}, 2 \mathrm{H}), 7.25-7.32(\mathrm{~m}, 3 \mathrm{H}), 3.99(\mathrm{~m}, 1 \mathrm{H}), 3.84(\mathrm{~s}$, 3H), 1.83-1.91 (m, 4H), 1.60-1.68 (m, 3H), 1.39 (app ddt, $J=3.3,3.3,13.1 \mathrm{~Hz}, 2 \mathrm{H})$, and 1.14 (app ddt, $J$ $=3.7,3.7,13.1 \mathrm{~Hz}, 1 \mathrm{H}) ;{ }^{13} \mathrm{C} \mathrm{NMR}\left(125 \mathrm{MHz}, \mathrm{CDCl}_{3}\right) \square 155.6,131.2,128.4,127.5,123.6,80.7,72.4$, 56.6, 54.0, 30.7, 25.5, and 25.3; HRMS-EI m/z: [M] ${ }^{+}$calcd for $\mathrm{C}_{16} \mathrm{H}_{19} \mathrm{NO}_{2}, 257.1411$; found, 257.1414.

$N$-Benzyl- $N$-tert-butoxycarbonyl-2-phenylethynylamine (9h). Reaction of a solution of carbamate 8d $(0.189 \mathrm{~g}, 0.912 \mathrm{mmol})$ in $3.6 \mathrm{~mL}$ of pyridine with KHMDS $(1.0 \mathrm{~mL}, 0.91 \mathrm{M}$ in THF, 0.91 $\mathrm{mmol}), \mathrm{CuI}(0.174 \mathrm{~g}, 0.914 \mathrm{mmol})$ in $2.8 \mathrm{~mL}$ of pyridine, and bromo alkyne 10a $(3.0 \mathrm{~mL}, 0.60 \mathrm{M}$ in benzene, $1.8 \mathrm{mmol}$ ) according to the general procedure gave $0.457 \mathrm{~g}$ of a dark red oil. Column chromatography on $50 \mathrm{~g}$ of silica gel (elution with benzene) provided $0.171 \mathrm{~g}(61 \%)$ of ynamide $\mathbf{9 h}$ as an orange oil: IR (neat): 3033, 2979, 2242, 1721, 1600, 1496, 1454, 1393, 1369, 1301, 1242, and $1155 \mathrm{~cm}^{-1}$; ${ }^{1} \mathrm{H}$ NMR (500 MHz, CDCl 3$) \square 7.49(\mathrm{~m}, 2 \mathrm{H}), 7.43(\mathrm{~m}, 2 \mathrm{H}), 7.38(\mathrm{~m}, 3 \mathrm{H}), 7.32(\mathrm{~m}, 2 \mathrm{H}), 7.28(\mathrm{~m}, 1 \mathrm{H}), 4.74$ (s, 2H), and $1.60(\mathrm{~s}, 9 \mathrm{H}) ;{ }^{13} \mathrm{C} \mathrm{NMR}\left(125 \mathrm{MHz}, \mathrm{CDCl}_{3}\right) \square 153.9,136.5,130.6,128.6,128.4,128.3,128.0$, 127.2, 123.7, 84.2, 82.7, 71.2, 53.1, and 28.1; HRMS-ESI $m / z:[\mathrm{M}+\mathrm{Na}]^{+}$calcd for $\mathrm{C}_{20} \mathrm{H}_{21} \mathrm{NO}_{2}, 330.1465$; found, 330.1452 . 
$N$-Benzyl- $N$-tert-butoxycarbonyl-5-(tert-butyldimethylsiloxy)-1-pentynylamine (9i). Reaction of a solution of carbamate $8 \mathbf{d}(0.207 \mathrm{~g}, 0.999 \mathrm{mmol})$ in $4.0 \mathrm{~mL}$ of pyridine with KHMDS $(1.1 \mathrm{~mL}, 0.91 \mathrm{M}$ in THF, $1.0 \mathrm{mmol}), \mathrm{CuI}(0.191 \mathrm{~g}, 1.00 \mathrm{mmol})$ in $3.0 \mathrm{~mL}$ of pyridine, and bromo alkyne $\mathbf{1 0 g}(3.3 \mathrm{~mL}, 0.60$ $\mathrm{M}$ in benzene, $2.0 \mathrm{mmol}$ ) according to the general procedure gave $0.706 \mathrm{~g}$ of a dark red oil. Column chromatography on $40 \mathrm{~g}$ of silica gel (gradient elution with $0.5-2 \%$ EtOAc-hexanes) provided $0.213 \mathrm{~g}$ (53\%) of ynamide 9i as a yellow oil: IR (neat): 3033, 2954, 2929, 2857, 2264, 1720, 1606, 1497, 1471, $1455,1391,1368,1295,1256,1162,1105$, and $836 \mathrm{~cm}^{-1} ;{ }^{1} \mathrm{H} \mathrm{NMR}\left(500 \mathrm{MHz}, \mathrm{CDCl}_{3}\right) \square 7.33(\operatorname{app} \mathrm{d}, J=$ $4.6 \mathrm{~Hz}, 2 \mathrm{H}), 7.29(\mathrm{~m}, 3 \mathrm{H}), 4.54(\mathrm{~s}, 2 \mathrm{H}), 3.64(\mathrm{t}, J=6.1 \mathrm{~Hz}, 2 \mathrm{H}), 2.33(\mathrm{~m}, 2 \mathrm{H}), 1.66(\mathrm{~m}, 2 \mathrm{H}), 1.48$ (br s, 9H), $0.90(\mathrm{~s}, 9 \mathrm{H})$, and $0.04(\mathrm{~s}, 6 \mathrm{H}) ;{ }^{13} \mathrm{C} \mathrm{NMR}\left(125 \mathrm{MHz}, \mathrm{CDCl}_{3}\right) \square 154.7,137.0,128.5,128.2,127.7$, 82.1, 74.7, 69.4, 61.6, 53.0, 32.2, 28.2, 26.0, 18.4, 15.0, and -5.2; HRMS-ESI $m / z:[\mathrm{M}+\mathrm{Na}]^{+}$calcd for $\mathrm{C}_{23} \mathrm{H}_{37} \mathrm{NO}_{3} \mathrm{Si}$, 426.2435; found, 426.2425 .

(R)-(+)-4-Benzyl-3-(2-phenylethynyl)-2-oxazolidinone (14). Reaction of a solution of oxazolidinone $11(0.225 \mathrm{~g}, 1.27 \mathrm{mmol})$ in $5.1 \mathrm{~mL}$ of pyridine with KHMDS (1.4 mL, $0.91 \mathrm{M}$ in THF, 1.3 $\mathrm{mmol}), \mathrm{CuI}(0.243 \mathrm{~g}, 1.28 \mathrm{mmol})$ in $3.6 \mathrm{~mL}$ of pyridine, and bromo alkyne $10 \mathrm{a}(4.2 \mathrm{~mL}, 0.60 \mathrm{M}$ in benzene, $2.5 \mathrm{mmol}$ ) according to the general procedure gave $0.555 \mathrm{~g}$ of a dark red oil. Column chromatography on $40 \mathrm{~g}$ of silica gel (gradient elution with 0-10\% EtOAc-hexanes) provided $0.262 \mathrm{~g}$ (74\%) of ynamide 14 as a light tan solid: $\mathrm{mp} 87-88^{\circ} \mathrm{C}$; IR $\left(\mathrm{CH}_{2} \mathrm{Cl}_{2}\right): 3060,3029,2917,2256,1777,1602$, 1497, 1476, 1454, 1442, 1411, 1285, 1210, 1158, and $1088 \mathrm{~cm}^{-1} ;{ }^{1} \mathrm{H}$ NMR $\left(500 \mathrm{MHz}, \mathrm{CDCl}_{3}\right) \square 7.49$ (m, 2H), 7.24-7.36 (m, 8H), $4.31(\mathrm{~m}, 2 \mathrm{H}), 4.12(\mathrm{~m}, 1 \mathrm{H}), 3.21(\mathrm{~m}, 1 \mathrm{H})$, and $3.00(\mathrm{~m}, 1 \mathrm{H}) ;{ }^{13} \mathrm{C}$ NMR $(125$ $\left.\mathrm{MHz}, \mathrm{CDCl}_{3}\right) \square 155.4,134.2,131.4,129.3,128.8,128.2,128.1,127.3,122.1,78.2,73.0,67.3,58.1$, and 37.6; HRMS-EI m/z: [M] $]^{+}$calcd for $\mathrm{C}_{18} \mathrm{H}_{15} \mathrm{NO}_{2}$, 277.1097; found, 277.1107.

(4R,5S)-(-)-1,5-Dimethyl-4-phenyl-3-(2-phenylethynyl)-2-imidazolidinone (15). Reaction of a solution of imidazolidinone $12(0.242 \mathrm{~g}, 1.27 \mathrm{mmol})$ in $5.0 \mathrm{~mL}$ of pyridine with KHMDS (1.4 mL, 0.91 $\mathrm{M}$ in THF, $1.3 \mathrm{mmol}), \mathrm{CuI}(0.243 \mathrm{~g}, 1.28 \mathrm{mmol})$ in $3.5 \mathrm{~mL}$ of pyridine, and bromo alkyne $10 \mathrm{a}(4.2 \mathrm{~mL}$, $0.60 \mathrm{M}$ in benzene, $2.5 \mathrm{mmol}$ ) according to the general procedure gave $0.563 \mathrm{~g}$ of a dark red solid. Column chromatography on $40 \mathrm{~g}$ of silica gel (gradient elution with 0-30\% EtOAc-hexanes) provided $0.222 \mathrm{~g}(60 \%)$ of ynamide 15 as a light purple solid: mp 187-188 ${ }^{\circ} \mathrm{C}$; IR $\left(\mathrm{CH}_{2} \mathrm{Cl}_{2}\right): 3054,2986,2240$, 1726, 1599, 1441, 1403, 1265, 1167, 896, and $739 \mathrm{~cm}^{-1} ;{ }^{1} \mathrm{H}$ NMR (500 MHz, $\left.\mathrm{CDCl}_{3}\right) \square 7.31-7.39$ (m, 3H), $7.24(\mathrm{~m}, 4 \mathrm{H}), 7.17(\mathrm{~m}, 3 \mathrm{H}), 5.02(\mathrm{~d}, J=8.9 \mathrm{~Hz}, 1 \mathrm{H}), 3.91(\mathrm{dq}, J=6.6,8.9 \mathrm{~Hz}, 1 \mathrm{H}), 2.83(\mathrm{~s}, 3 \mathrm{H})$, and 
$0.76(\mathrm{~d}, J=6.6 \mathrm{~Hz}, 3 \mathrm{H}) ;{ }^{13} \mathrm{C} \mathrm{NMR}\left(125 \mathrm{MHz}, \mathrm{CDCl}_{3}\right) \square 157.6,134.7,131.2,128.5,128.5,128.0,127.7$, 127.2, 123.4, 81.7, 71.4, 64.1, 55.6, 28.9, and 14.8; HRMS-ESI $m / z$ : $[\mathrm{M}+\mathrm{H}]^{+}$calcd for $\mathrm{C}_{19} \mathrm{H}_{18} \mathrm{~N}_{2} \mathrm{O}$, 291.1492; found, 291.1490.

$N$-Benzyl- $N$-(p-toluenesulfonyl)-2-phenylethynylamine (16). Reaction of a solution of sulfonamide $13(0.268 \mathrm{~g}, 1.03 \mathrm{mmol})$ in $4.1 \mathrm{~mL}$ of pyridine with KHMDS (1.1 mL, $0.91 \mathrm{M}$ in THF, 1.0 $\mathrm{mmol}), \mathrm{CuI}(0.197 \mathrm{~g}, 1.03 \mathrm{mmol})$ in $3.1 \mathrm{~mL}$ of pyridine, and bromo alkyne $10 \mathrm{a}(3.4 \mathrm{~mL}, 0.60 \mathrm{M}$ in benzene, $2.0 \mathrm{mmol}$ ) according to the general procedure gave $0.561 \mathrm{~g}$ of a dark red oil. Column chromatography on $35 \mathrm{~g}$ of silica gel (gradient elution with 0-10\% EtOAc-hexanes) provided $0.291 \mathrm{~g}$ (78\%) of ynamide 16 as a pale yellow solid: $\mathrm{mp} 82-83{ }^{\circ} \mathrm{C}$; IR $\left(\mathrm{CH}_{2} \mathrm{Cl}_{2}\right): 3035,2928,2235,1598,1495$, 1456, 1443, 1366, 1171, and $1090 \mathrm{~cm}^{-1} ;{ }^{1} \mathrm{H} \mathrm{NMR}\left(500 \mathrm{MHz}, \mathrm{CDCl}_{3}\right) \square 7.89$ (d, J=8.2 Hz, 2H), $7.41(\mathrm{~m}$, 2H), $7.36(\mathrm{~m}, 5 \mathrm{H}), 7.28-7.33(\mathrm{~m}, 5 \mathrm{H}), 4.65(\mathrm{~s}, 2 \mathrm{H})$, and $2.46(\mathrm{~s}, 3 \mathrm{H}) ;{ }^{13} \mathrm{C} \mathrm{NMR}\left(125 \mathrm{MHz}, \mathrm{CDCl}_{3}\right) \square$ $144.8,134.5,134.4,131.1,129.8,128.9,128.5,128.4,128.2,127.7,127.7,122.7,82.7,71.4,55.7$, and 21.6; HRMS-EI $m / z$ : [M] $]^{+}$calcd for $\mathrm{C}_{22} \mathrm{H}_{19} \mathrm{NO}_{2} \mathrm{~S}, 361.1131$; found, 361.1135 .

$N$-Benzyl- $N$-(p-toluenesulfonyl)-1-octynylamine (17). Reaction of a solution of sulfonamide 13 $(0.260 \mathrm{~g}, 0.995 \mathrm{mmol})$ in $4.0 \mathrm{~mL}$ of pyridine with KHMDS (1.1 mL, $0.91 \mathrm{M}$ in THF, $1.0 \mathrm{mmol}), \mathrm{CuI}$ $(0.191 \mathrm{~g}, 1.00 \mathrm{mmol})$ in $3.0 \mathrm{~mL}$ of pyridine, and bromo alkyne 10e $(3.3 \mathrm{~mL}, 0.60 \mathrm{M}$ in benzene, 2.0 $\mathrm{mmol}$ ) according to the general procedure gave $0.453 \mathrm{~g}$ of a dark red oil. Column chromatography on 35 $\mathrm{g}$ of silica gel (gradient elution with 0-5\% EtOAc-hexanes) provided $0.155 \mathrm{~g}$ (42\%) of ynamide 17 as a yellow oil: IR (neat): 3033, 2930, 2858, 2254, 1597, 1497, 1455, 1365, 1169, $1091 \mathrm{~cm}^{-1}$; ${ }^{1} \mathrm{H}$ NMR (500 $\left.\mathrm{MHz}, \mathrm{CDCl}_{3}\right) \square 7.77$ (d, $\left.J=8.2 \mathrm{~Hz}, 2 \mathrm{H}\right), 7.31(\mathrm{~d}, J=8.2 \mathrm{~Hz}, 2 \mathrm{H}), 7.29(\mathrm{~m}, 5 \mathrm{H}), 4.46(\mathrm{~s}, 2 \mathrm{H}), 2.44(\mathrm{~s}$, $3 \mathrm{H}), 2.18(\mathrm{t}, J=7.0 \mathrm{~Hz}, 2 \mathrm{H}), 1.38$ (app quartet, $J=7.0 \mathrm{~Hz}, 2 \mathrm{H}), 1.19-1.29(\mathrm{~m}, 6 \mathrm{H})$, and $0.89(\mathrm{t}, J=7.2$ $\mathrm{Hz}, 3 \mathrm{H}) ;{ }^{13} \mathrm{C} \mathrm{NMR}\left(125 \mathrm{MHz}, \mathrm{CDCl}_{3}\right) \square 144.4,134.9,134.7,129.7,128.8,128.5,128.2,127.7,73.4$, 70.9, 55.6, 31.4, 28.8, 28.4, 22.6, 21.7, 18.4, and 14.2; HRMS-ESI $m / z$ : $[\mathrm{M}+\mathrm{Na}]^{+}$calcd for $\mathrm{C}_{22} \mathrm{H}_{27} \mathrm{NO}_{2} \mathrm{~S}$, 392.1655; found, 392.1645 . 


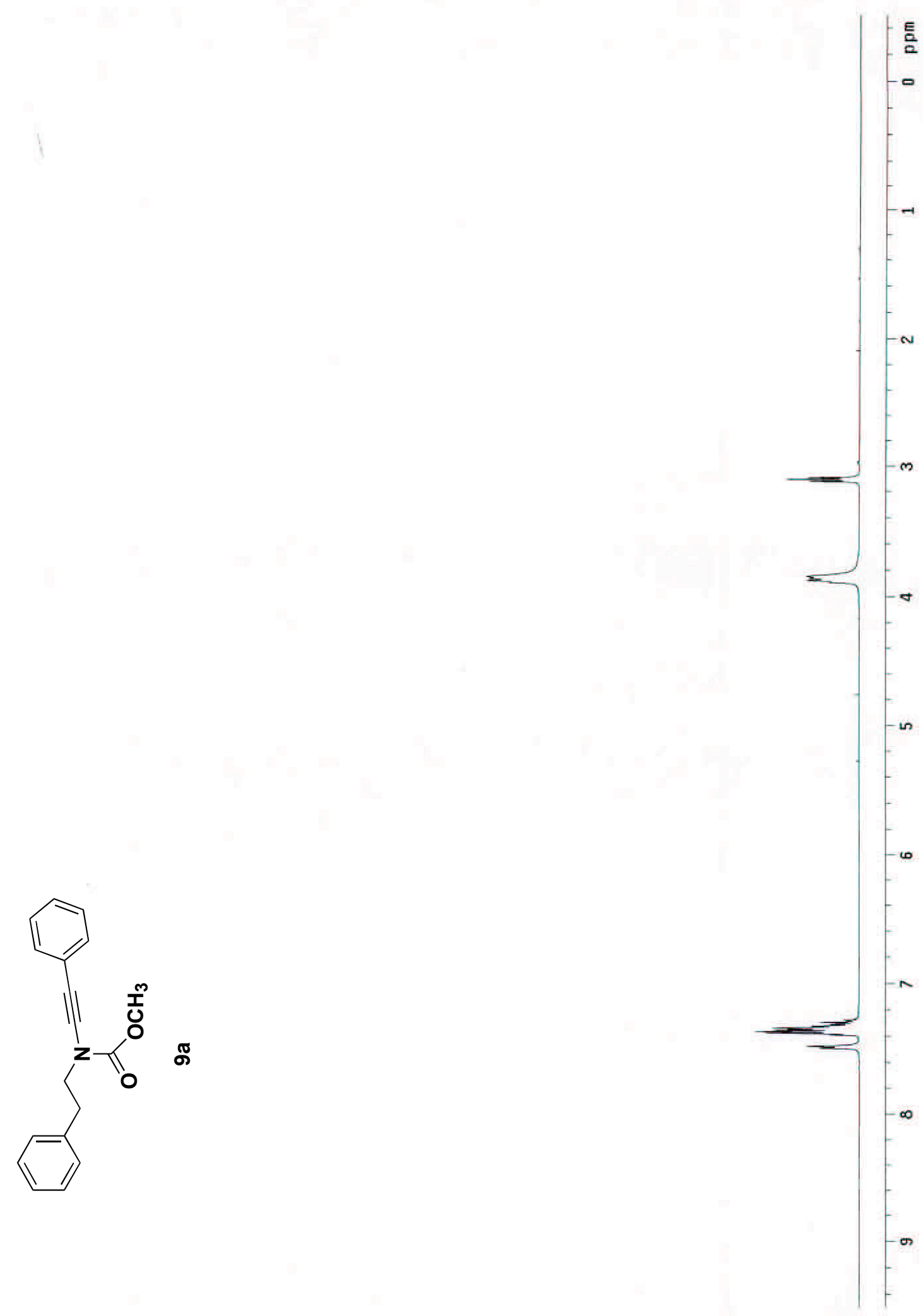




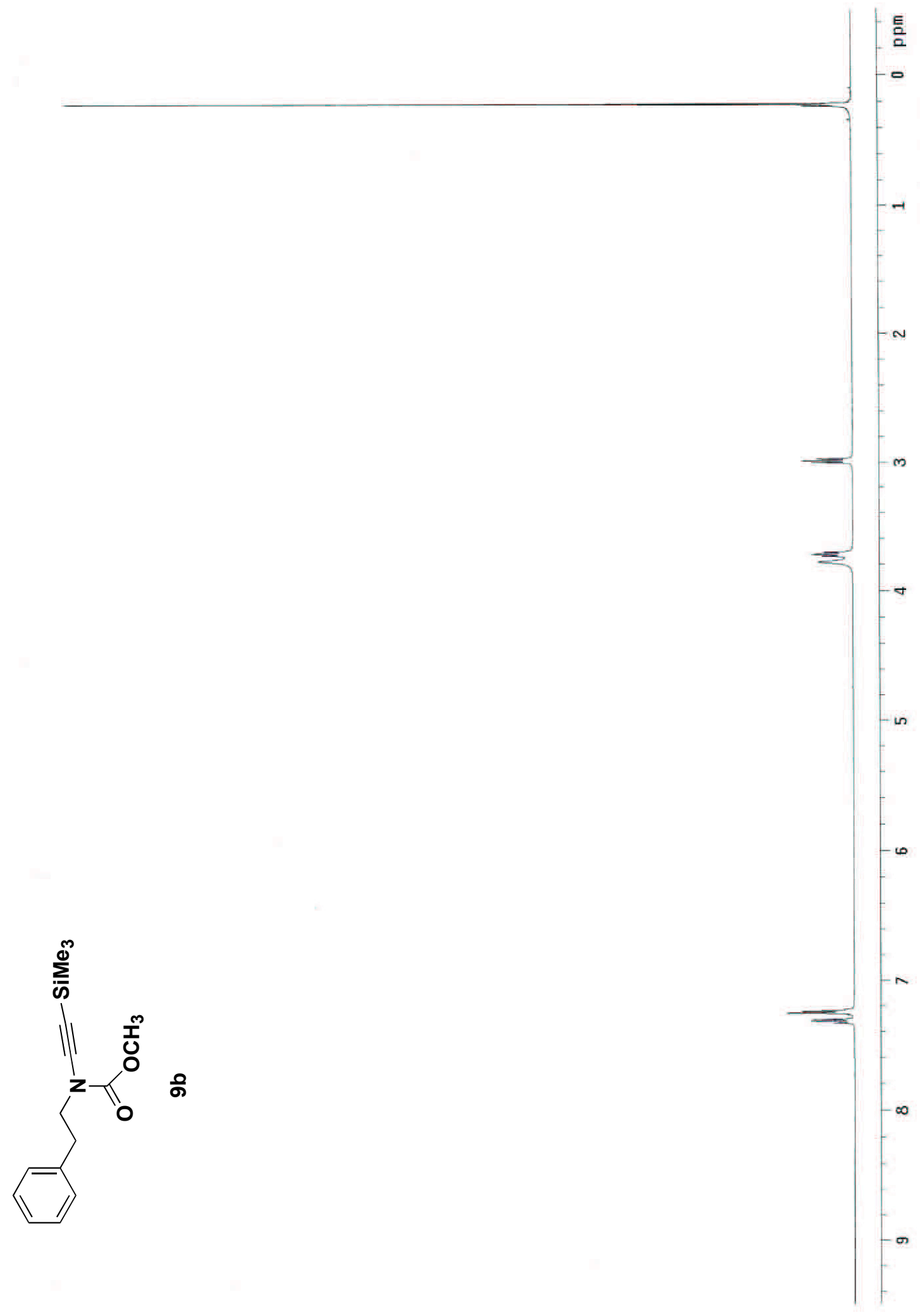




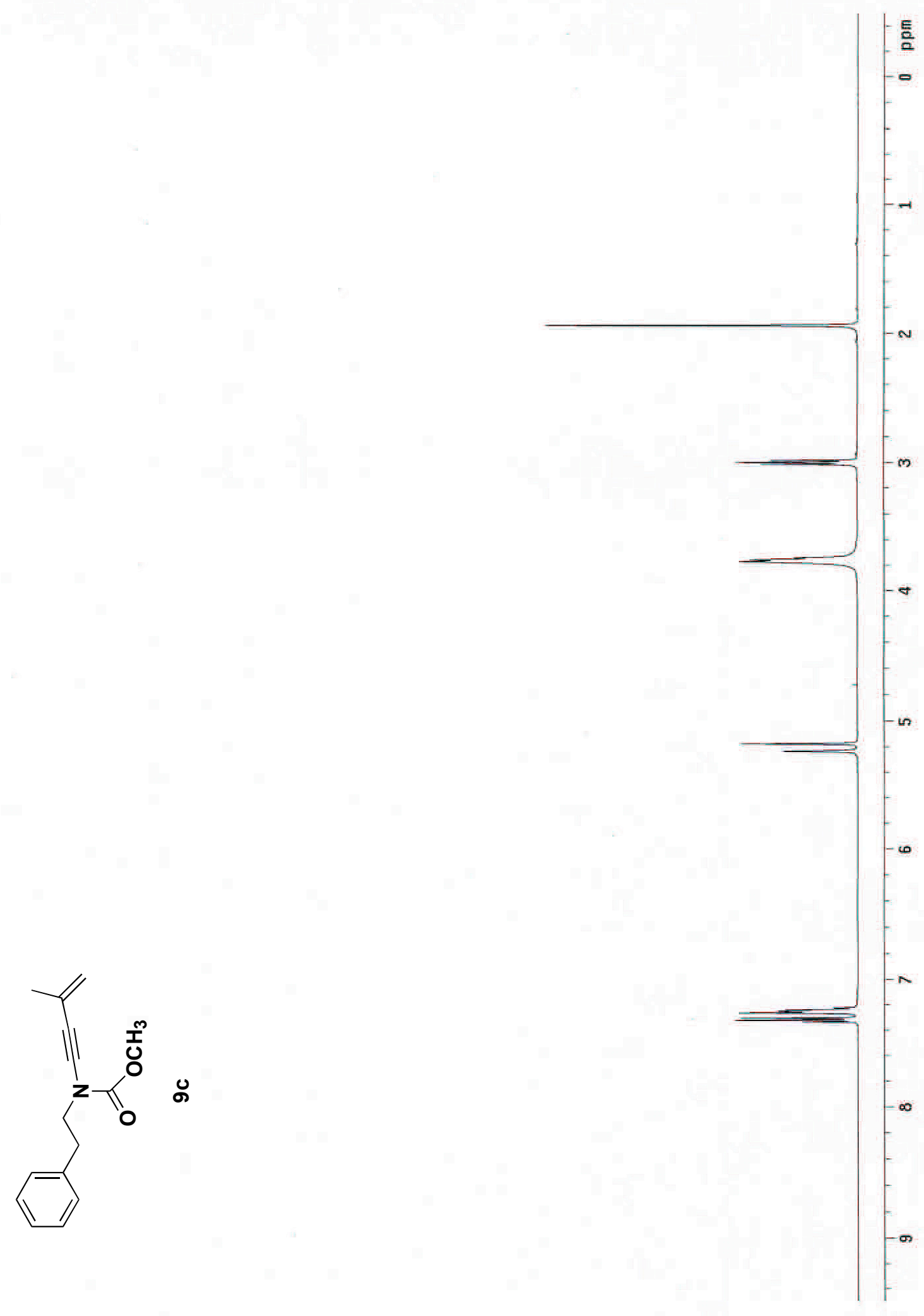




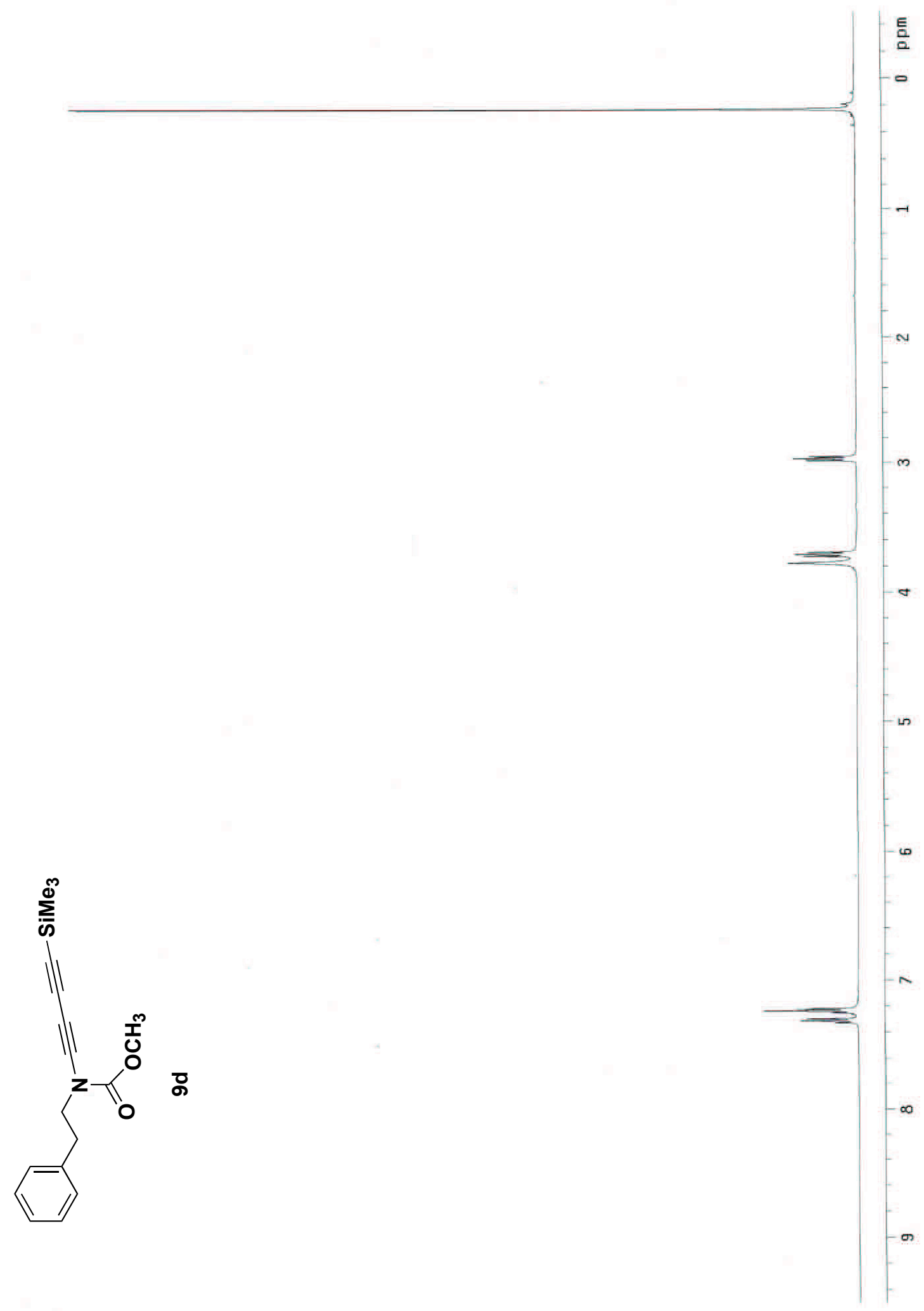




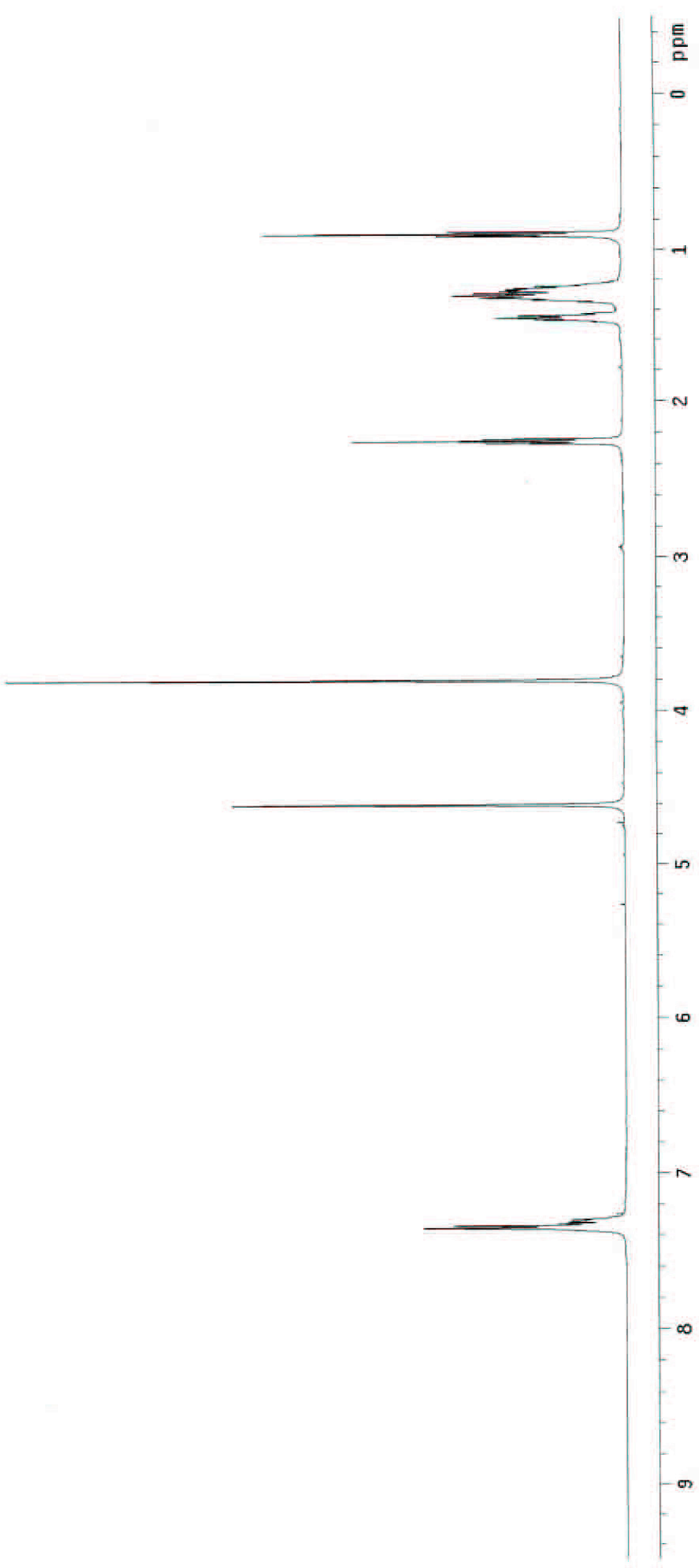




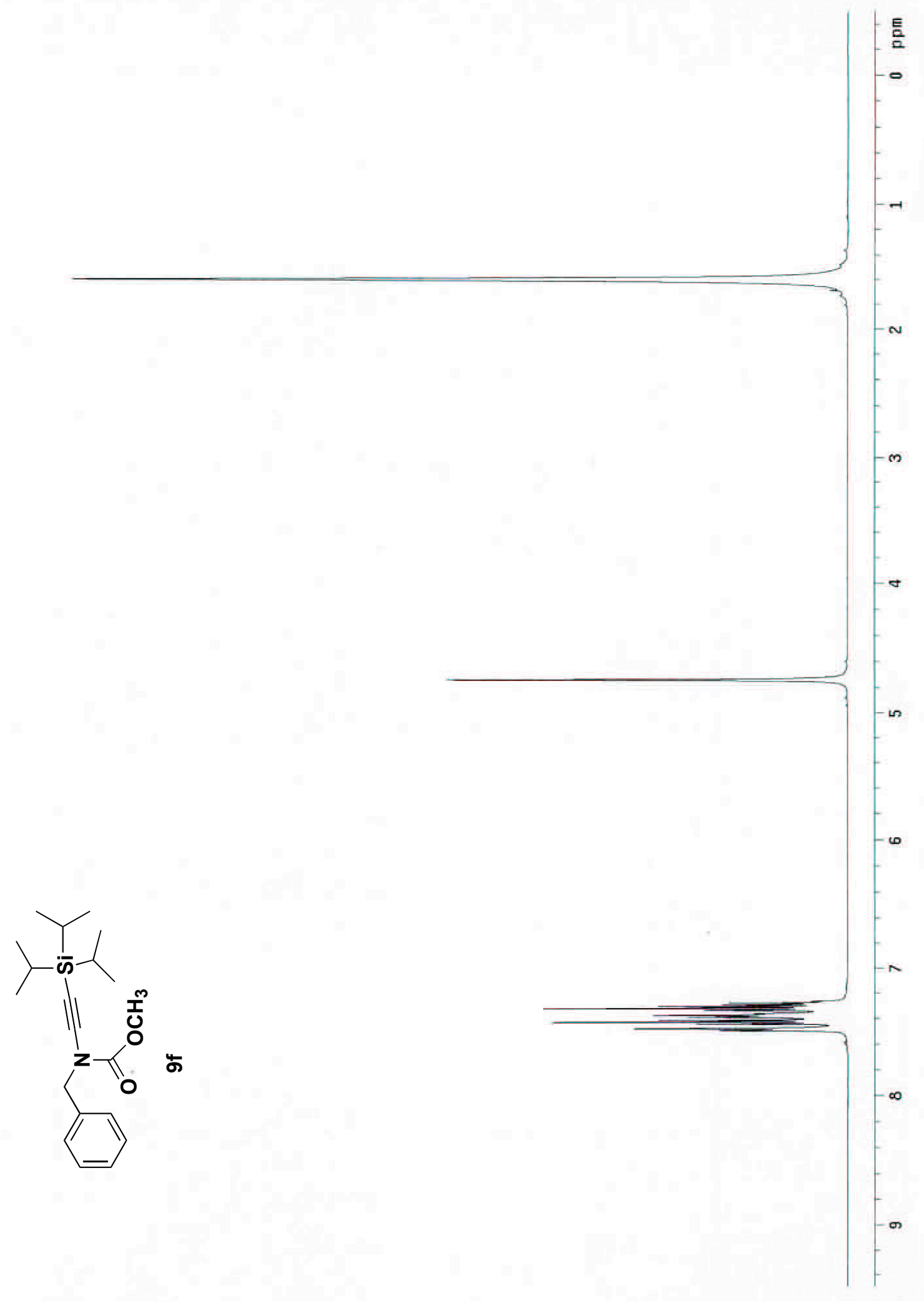




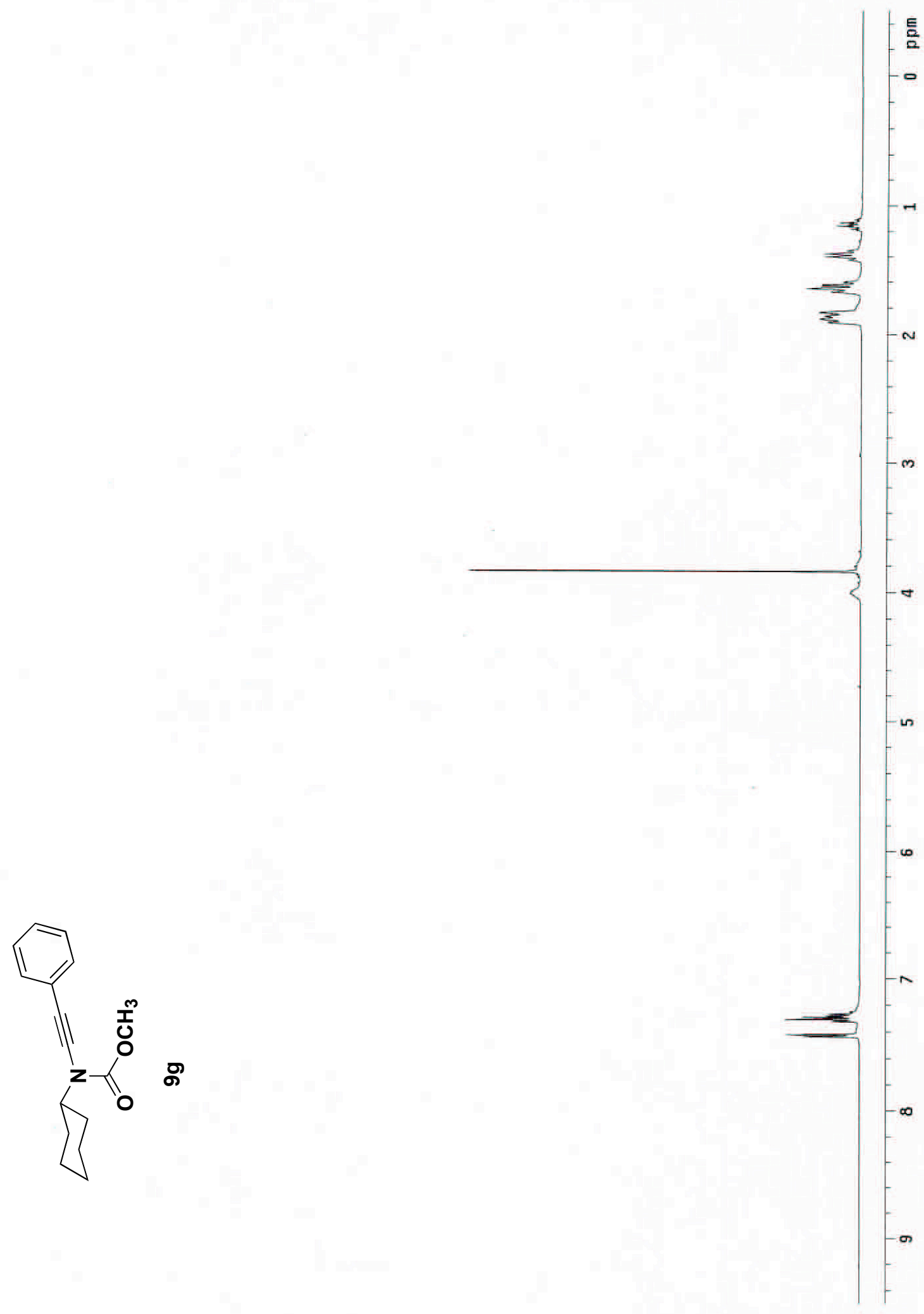




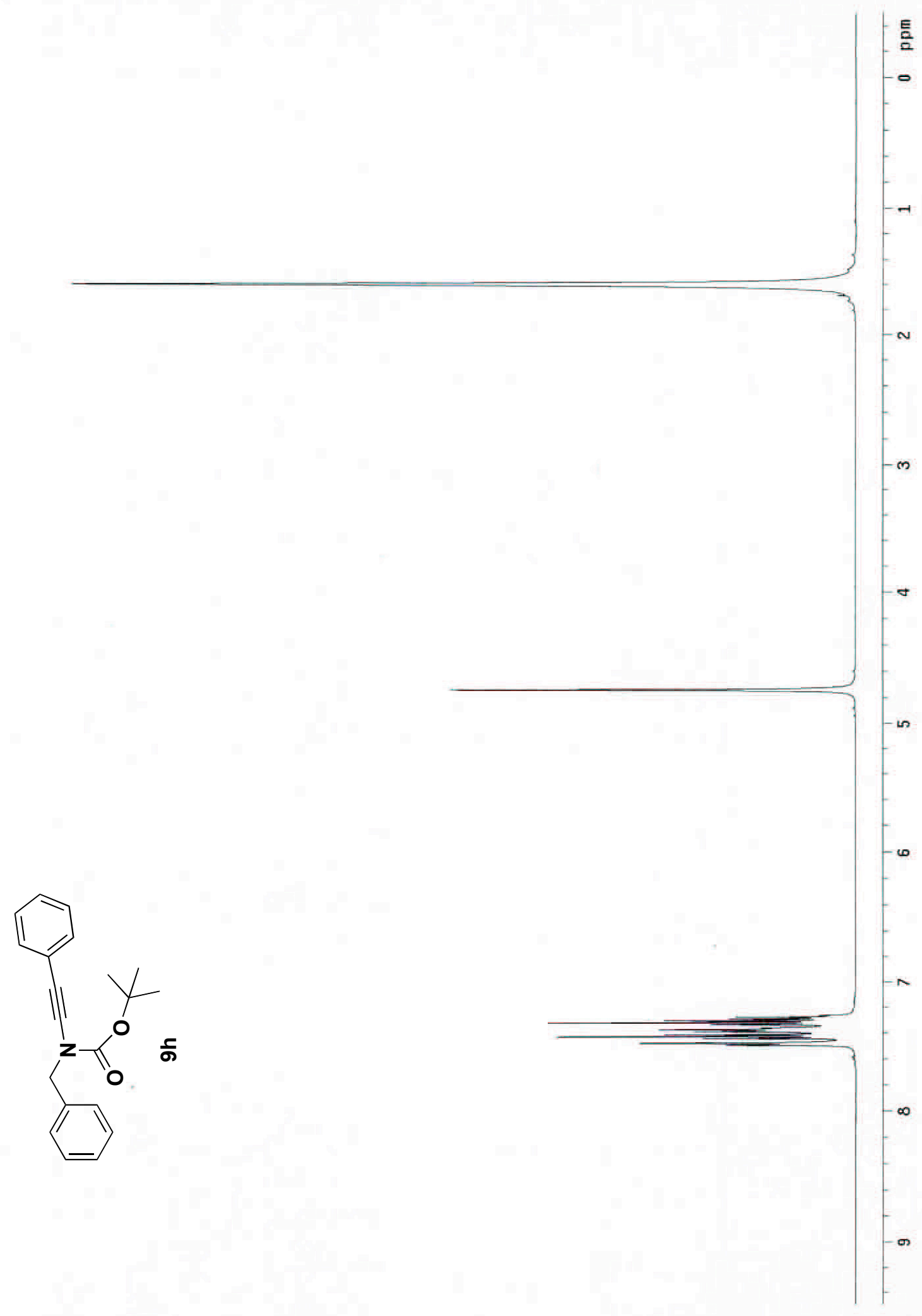




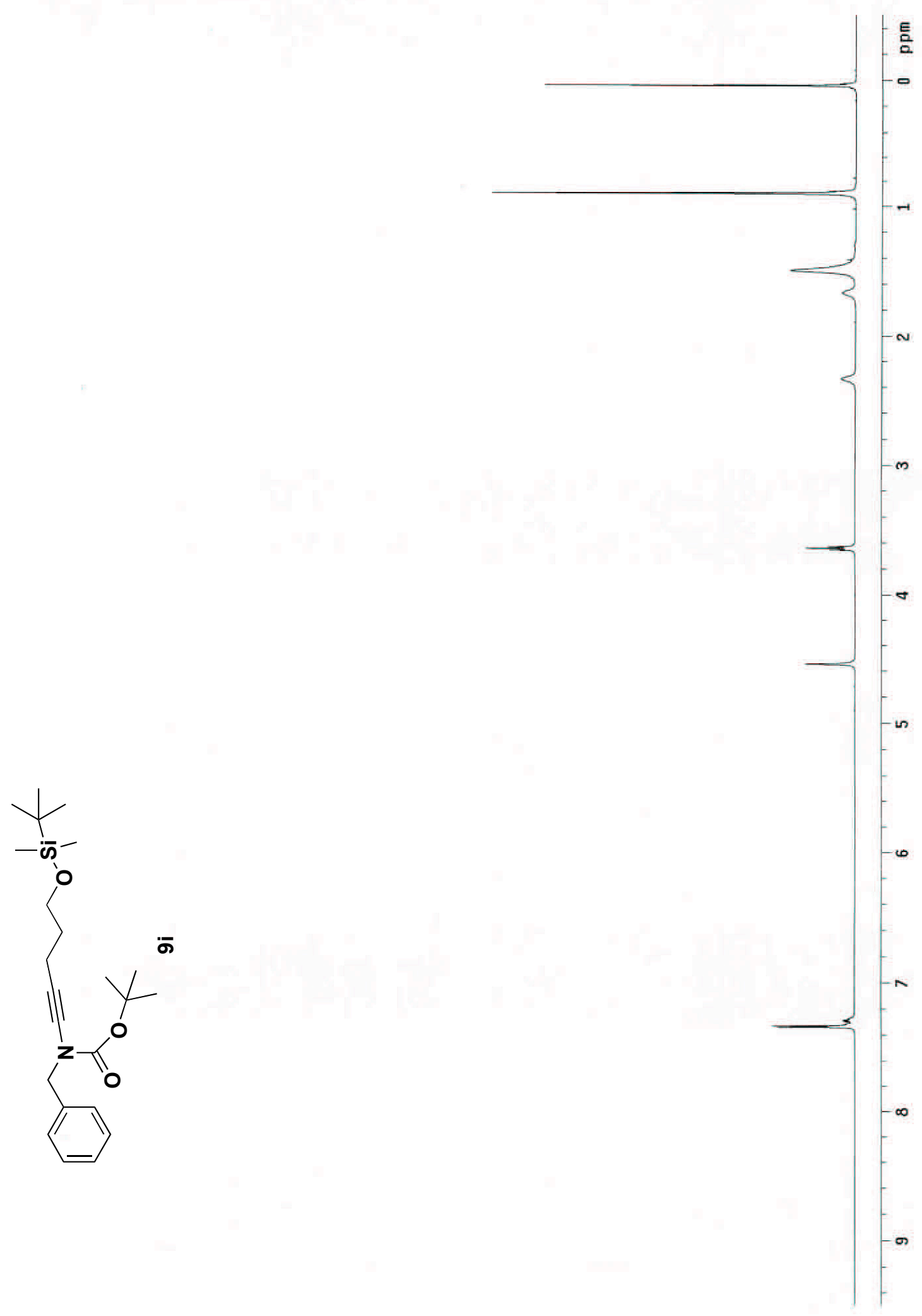




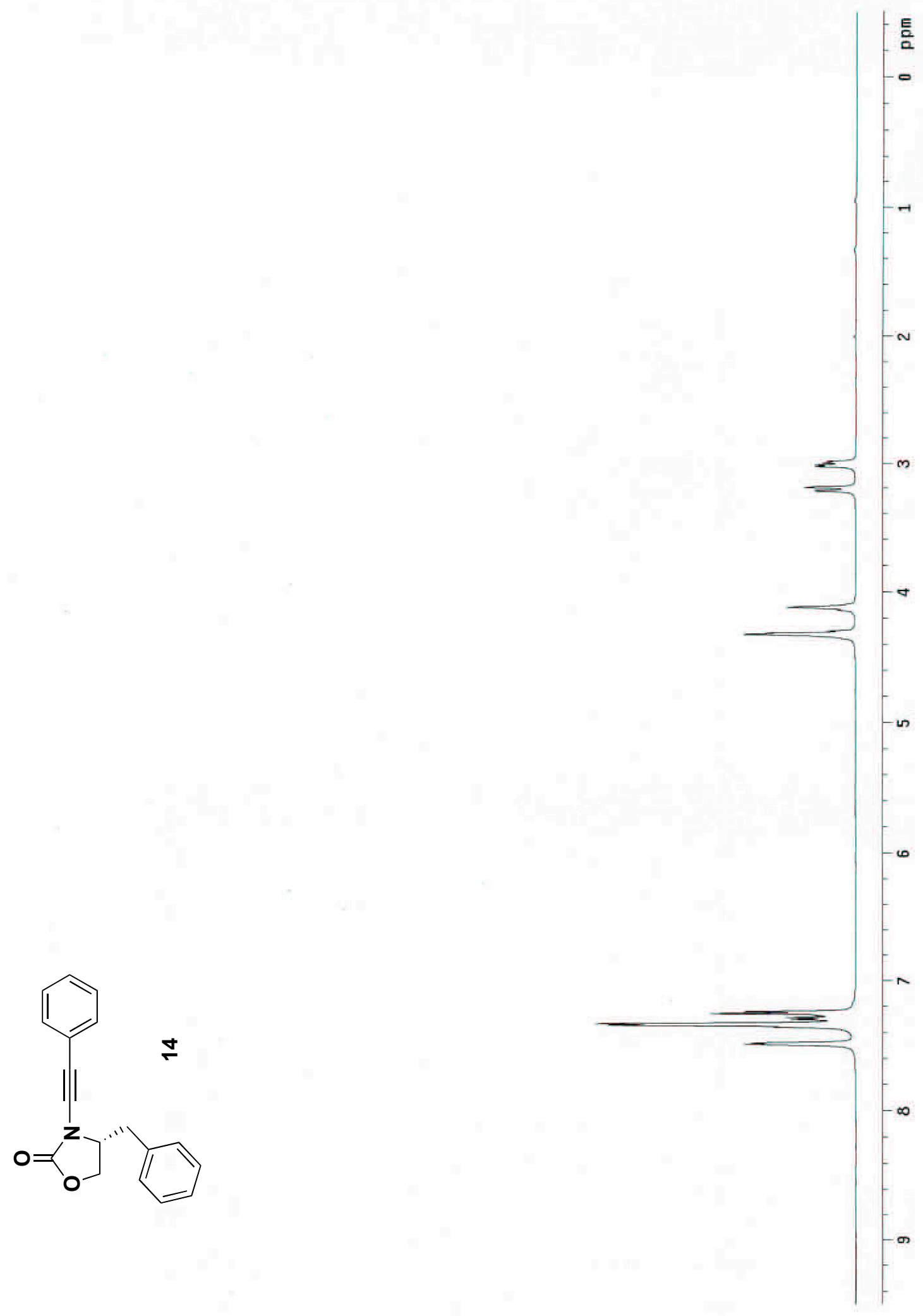




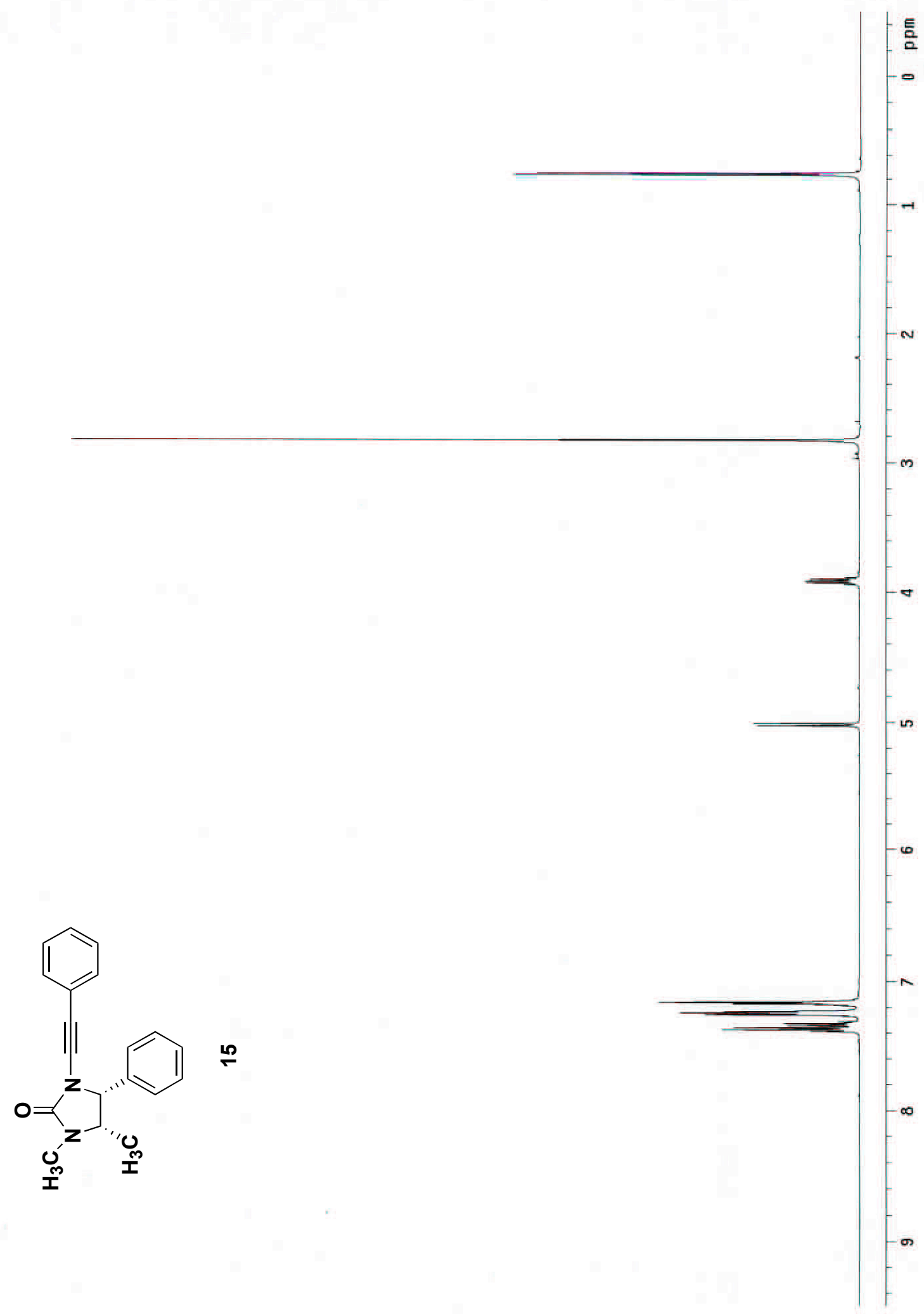




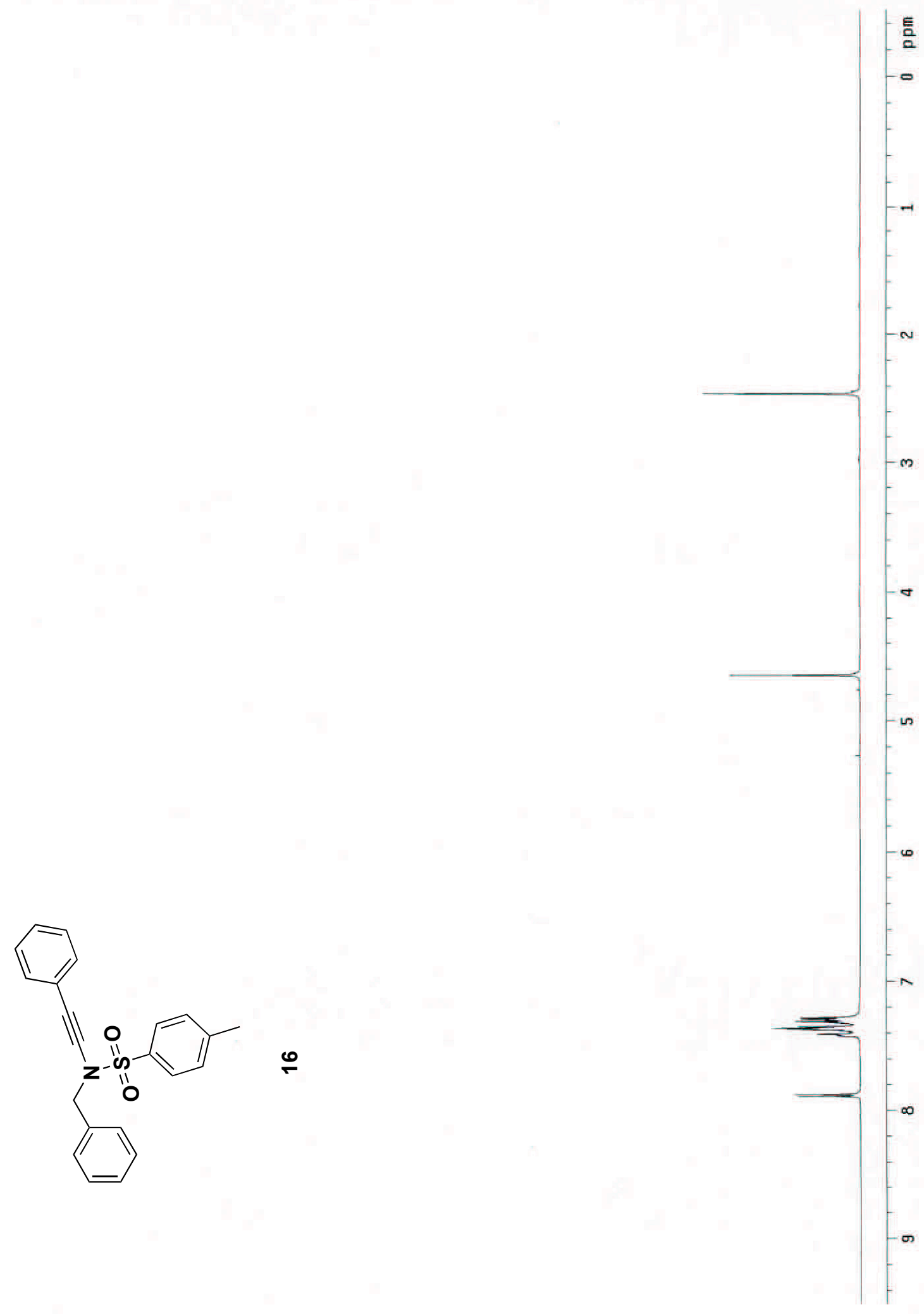



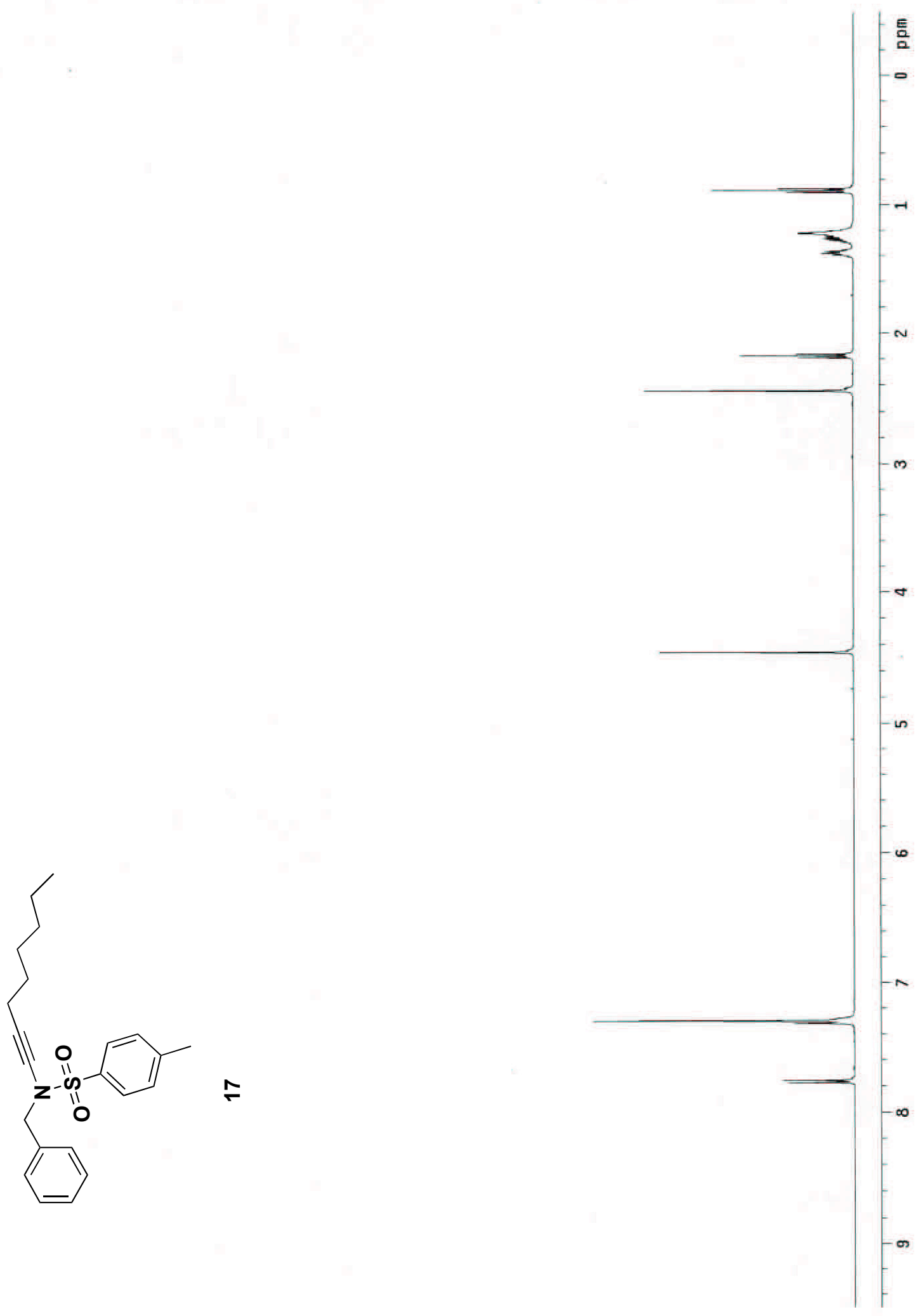